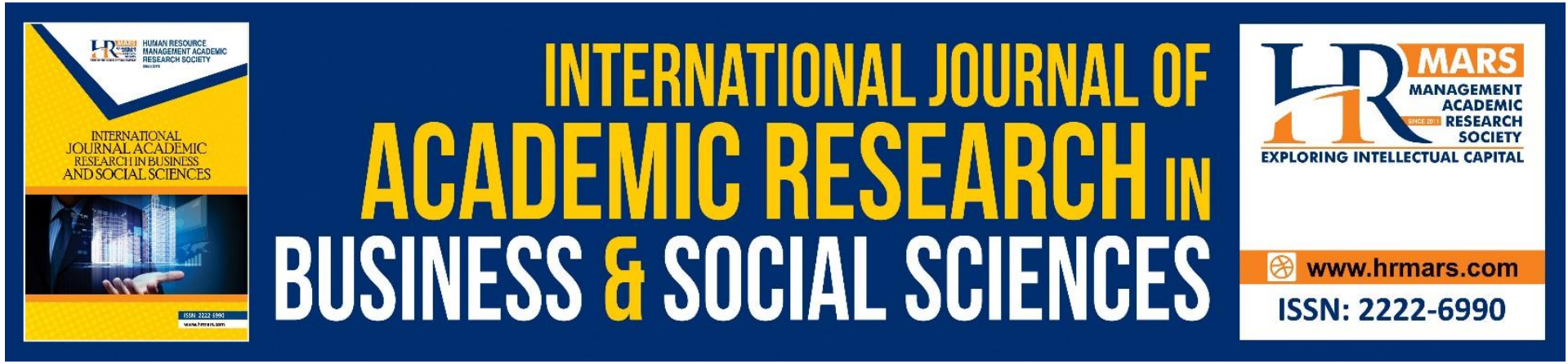

\title{
Contractual Risk and Performance of Manufacturing Firms in Kenya
}

James Mutinda Kithuka, Wario Guyo, David Kiarie

To Link this Article: http://dx.doi.org/10.6007/IJARBSS/v11-i9/11108

DOI:10.6007/IJARBSS/v11-i9/11108

Received: 10 July 2021, Revised: 12 August 2021, Accepted: 28 August 2021

Published Online: 16 September 2021

In-Text Citation: (Kithuka et al., 2021)

To Cite this Article: Kithuka, J. M., Guyo, W., \& Kiarie, D. (2021). Contractual Risk and Performance of Manufacturing Firms in Kenya. International Journal of Academic Research in Business and Social Sciences, 11(9), 1108-1119.

\section{Copyright: @ 2021 The Author(s)}

Published by Human Resource Management Academic Research Society (www.hrmars.com)

This article is published under the Creative Commons Attribution (CC BY 4.0) license. Anyone may reproduce, distribute, translate and create derivative works of this article (for both commercial and non-commercial purposes), subject to full attribution to the original publication and authors. The full terms of this license may be seen at: http://creativecommons.org/licences/by/4.0/legalcode

Vol. 11, No. 9, 2021, Pg. 1108 - 1119

Full Terms \& Conditions of access and use can be found at http://hrmars.com/index.php/pages/detail/publication-ethics 


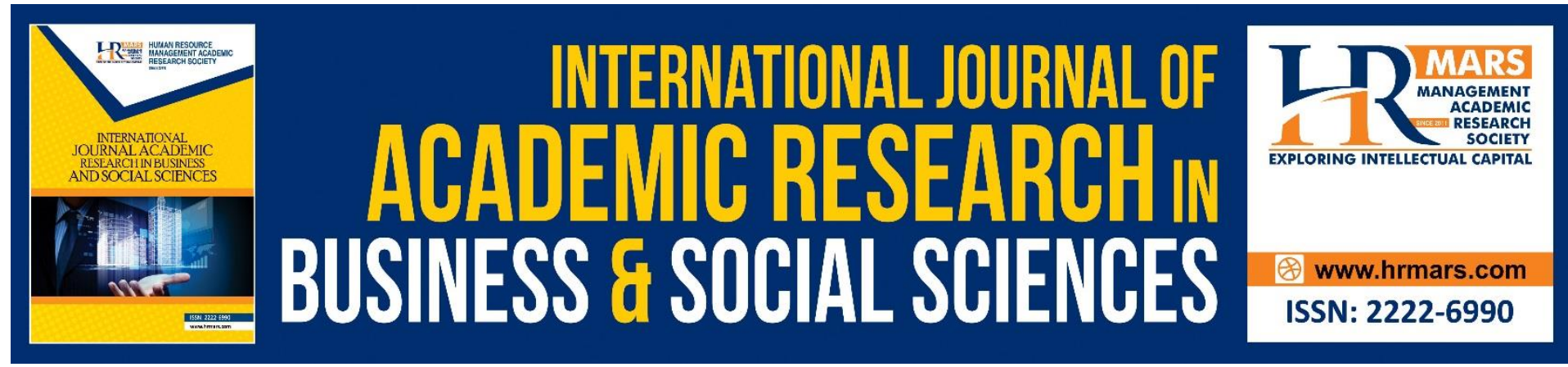

\title{
Contractual Risk and Performance of Manufacturing Firms in Kenya
}

\author{
James Mutinda Kithuka \\ Jomo Kenyatta University of Agriculture and Technology (JKUAT)
Dr. Wario Guyo, PhD, Dr. David Kiarie, PhD JKUAT, KENYA

\begin{abstract}
The study sought to examine the influence of contractual risk on performance of manufacturing firms in Kenya. With the growing need for logistics outsourcing among the manufacturing firms, the risks surrounding the entire process are also on the rise. This comes at a time when most of the manufacturing firms are at the verge of minimizing costs and sustaining their performance, while a couple of these companies are facing performance challenges. It therefore remains unclear whether the contractual risk as one of the logistics outsourcing risks could have any influence on the performance of these firms, hence the subject of the study. Both descriptive and explanatory research designs were adopted. The unit of observation was the supply chain administrators of manufacturing firms in Kenya. Stratified sampling was conducted on all the one thousand one hundred and twenty three manufacturing firms registered by KAM, simple random sampling was carried out on the strata to identify a sample size of 295 firms. The study relied mainly on primary data which was collected through semi-structured questionnaires that were administered to administrators charged with the management of supply chain within the selected firms. Data analysis was done using descriptive statistics and inferential statistics through SPSS version 24. The findings from the study revealed that contractual risk had a significant and positive influence on the performance of manufacturing firms in Kenya. Information flow had a significant moderating effect on the relationship between contractual risk and performance of manufacturing firms. It was concluded that through the contractual risk and managing the risks appropriately, the manufacturing firms are able to save on operational costs and achieve the best out of outsourcing logistics, thus enhancing performance.
\end{abstract}

Keywords: Contractual Risk, Logistics Outsourcing, Information Flow, Firm Performance, Manufacturing Firms

\section{Introduction}

\section{Background of the Study}

As a way of saving on operational costs and meeting the efficiency and effectiveness needs by the customers, companies are upholding outsourcing of their logistics from external logistics service providers. This has been amplified as one of the ways through which modern 
businesses are maximizing their performance and enhancing the effective flow of their logistics across the supply chain network. However, outsourcing logistics has been surrounded by many risks, which a time they may be out of control for the outsourcing firms. One of these risks is contractual risk. According to Waters (2014), contractual risk is the risk that a third party logistic provider is not in position to meet all requirements in expected quality or required time. Both the service provider and company are not in position to meet their contractual commitments. However, resource limitation on the side of the logistics provider may impinge on its capability to complete all contracted tasks in a demanding season hence interfering with the results expected from the whole process (Huo, 2015).

Zhu et al (2017) noted that the term outsourcing is used to embrace an extremely extensive collection of different measures. Nonetheless, outsourcing entities have universal interests which are based in reassigning to a third party the responsibility for performance of a particular service or function with a consequential lack of direct control. The logistics outsourcing contract is considered vital in maintaining the balance of power between the firm and the logistics service importance of the subject matter.

Poor outsourcing logistics contracts led to the end of the relationship and besides great losses in terms of financial capital (Zailani et al., 2017). Comprehensive contracts create, allocate and defend value as well as coordinate communication, inspiration and control in a company. They are resources not only for managing uncertainties between parties but also for administering commitments (Norrman, 2012). Other authors also emphasized the substance of such written agreements, underlining the fact that excellent contracts mitigate future ambiguities and disagreements and proposed that negotiation of contracts be handled perfectly (Muresan, et al., 2012).

There appeared to be no published research and work on the theme of contractual issues with logistics outsourcing though, there are a number of journals on logistics outsourcing. Razzaque and Chang (2010) did a comprehensive review on the outsourcing of the logistics function. This literature can be generally categorized according to different focus areas. Some of these focus areas included; logistics practices, usage of 3PL services, present state and future trends, strategies and performance measurements. In addition, there were a few studies which deal with the concerns and general risks related to this logistics outsourcing (Mokrini et al., 2016).

Manufacturing is to put together or process raw material into a finished produce, especially by means of a significant industrial operation (KAM, 2019). On average the sector has been growing at a rate lower than the economy, which dipped to $4.9 \%$ in 2017 . This indicate a reducing contribution of manufacturing sector to GDP over time hence it can be argued that the country is going through premature deindustrialization in a context where manufacturing and industry are still moderately under-developed. The Kenyan manufacturing industry continue to grow from strength to strength in spite of challenges in economic status of the country. As at December 2019, there were over 1123 registered multi-sector manufacturing firms in Kenya. These companies produce different products and vary in size which is determined by the number of staff they employ. Through export of their products, the industry has the capacity to generate foreign exchange earnings which will enhance the country's economy and create job opportunities. The country's share of manufacturing exports to the international market is projected to be about 0.02 percent which is favorable compared with its immediate East Africa neighbors (Kenya Institute for Public Policy Research and Analysis, 2013). 


\section{Statement of the Problem}

The manufacturing sector in Kenya had a lower growth of 3.6\% in the first quarter of 2016 compared to $4.1 \%$ growth in the first quarter of 2015. In the third quarter of 2017 the sector's growth rate was 1.9\% compared with 3.3\% in the same quarter in 2015 (KNBS, 2017). According to KAM, manufacturing priority agenda (2019), the weak performance has been attributed to high production and logistics costs, influx of counterfeits, drought incidences and volatility in international oil prices. While the empirical evidence has shown some give relationship between outsourcing and performance results, other reports give no significant or sometimes negative results (Wambua, 2017). However, there is scanty research on the influence of contractual risk on the performance of manufacturing firms. Therefore, to address this gap, this study sought to assess the influence of contractual risk on performance of manufacturing firms in Kenya.

\section{Study Objectives}

1. To determine the influence of contractual risk on performance of manufacturing firms in Kenya

2. To examine the moderating effect of information flow on the influence of contractual risk and performance of manufacturing firms in Kenya

\section{Research Hypotheses}

$\mathbf{H}_{\mathrm{A} 1}$ : There is a positive significant influence of contractual risk on performance of manufacturing firms in Kenya

$\mathbf{H}_{\mathrm{A2}}$ : There is a positive significant moderating effect of information flow on influence of contractual risk and performance of manufacturing firms in Kenya

\section{Literature Review Theoretical Framework}

The study was informed by contractual theory. The theory dates back in 1960s after Kenneth Arrow conducted the first formal research on contractual theory and found that to implement an outsourcing strategy, a legally bounding agreement should be in place to set the institutional framework and clearly define each party's rights, duties, and responsibilities. The contract should specify goals, policies, practices, and strategies on which the arrangement is based on (Luo, 2002). Properly written contracts prevents uncertainties arising from nonperformance, misinterpretation, and also reduces ambiguity likely to be faced by firm decision making process.

The contract sets a means for difference solving and legal experts emphasize the need for comprehensive contract which can serve as a reference point specifying how the client and the vendor interact (Kem \& Willcocks, 2000). According to Wallenburg (2010) the companies that search to outsource logistics should have an agreement with distinct clauses to safeguard against conflicts of interest. At the same time provide a solid and reliable foundation for the relationship and ultimately minimizing the risk of failure for both partners. This theory provided information useful on analyzing the influence of contractual risk on performance of manufacturing firms in Kenya. 


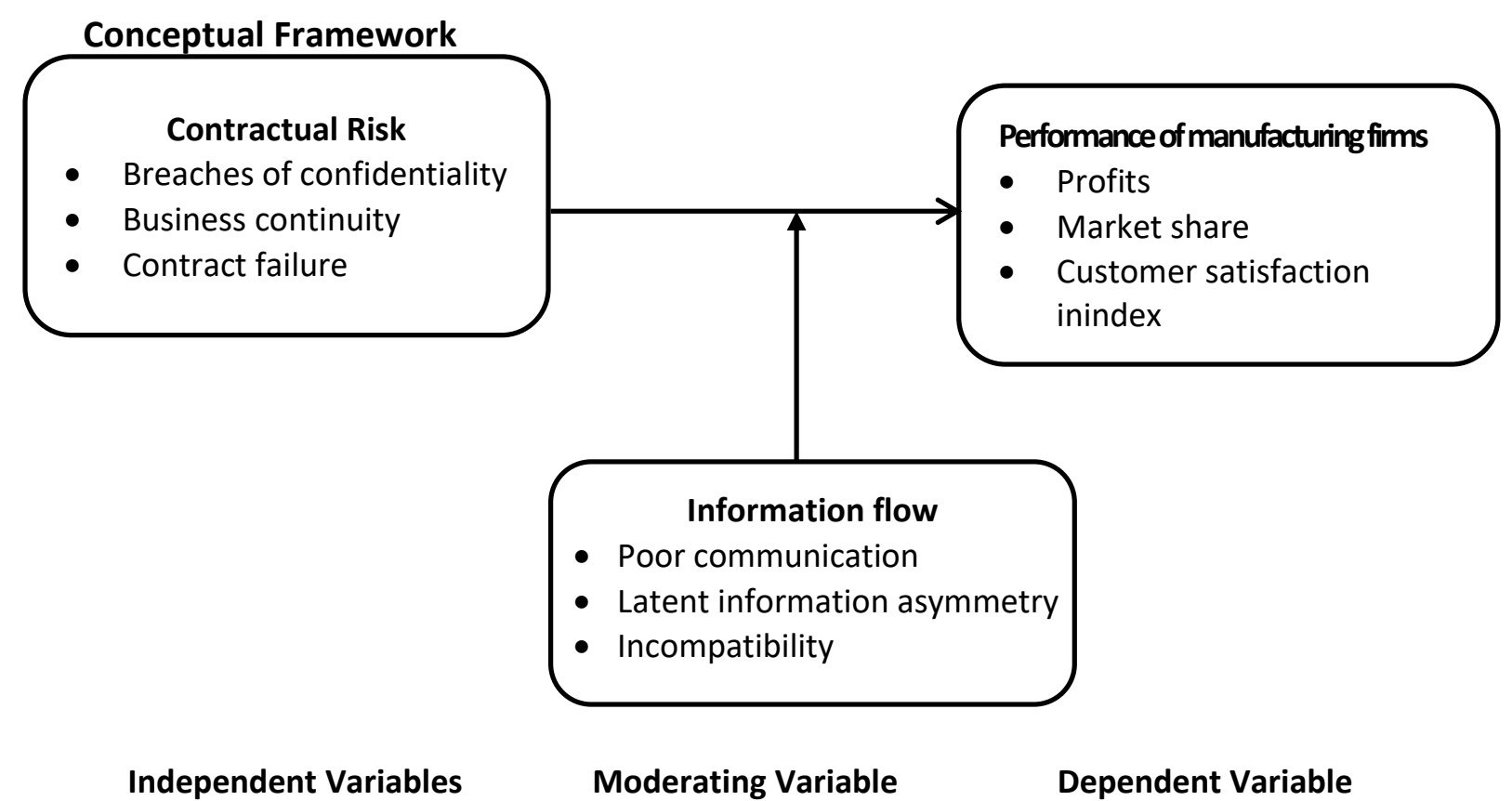

Figure 1: Conceptual Framework

\section{Empirical Review}

Mbachu and Taylor (2014) analysed the impact of contractual risk on the construction industry in New Zealand. The authors also sought to analyse the possible mitigation measures to these risks. The findings revealed that contractual risk was among the key determinants of the success of a project such that the ability of the contractors to deliver and the ability to have the right skills was possible risks that the projects encountered as far as the contractors were concerned. Mbachu and Taylor (2014) however established that through early involvement of the contractors and bringing them closer to the organization, it was possible to mitigate the contractual risk. They further recommended the need for continuous training of the suppliers and contractors, as a way of minimizing the occurrence of the contractual risk.

In the study of Sauvage and Haouari (2011) the authors put the effort in sketch a conceptual model of risk management applicable to logistics outsourcing. Their outcomes demonstrate that risk management could be an innovative tool supporting the achievement of logistics outsourcing. Hsiao et al. (2010) empirically surveyed if outsourcing diverse logistics activities causes variances in logistics service quality. They analyzed outsourcing of four ranks of logistics activities; delivery reliability, flexibility and lead time. Their conclusions exhibited that these outsourcing activities have no direct impact on service performance.

Gitahi and Tumuti (2019) did a study on the impact of management of contracting risks on performance of construction projects in Kilifi County, Kenya. The authors subdivided the contractual risk into four other risks which are financial risks, technical risks, scheduling risks and health and safety risks. They surveyed 73 construction projects in the county and specifically focused on the technical staff in these projects. The findings revealed that the contracting risks were critical in determining the performance of the projects hence managing these risks was essential for the success of the projects. According to Gitahi and Tumuti (2019), as a results of poor management of the contractual risk, companies have recorded declined performance in their projects which is characterized by poor delivery of the expected services and inappropriate handling of the project processes. 


\section{Methodology}

The study utilized jointly descriptive and explanatory research designs which allow for both observational data and formulation of a problem for more accurate investigations (Bordens $\&$ Abbott, 2014). Both provide the collection of relevant evidence with minimal expenditure of effort, time and funds; the resolve of the research transpires to be an accurate descriptive of condition and investigation of the affiliation between variables.

The study population was all the manufacturing firms in Kenya and the target population was all the manufacturing companies listed by Kenya Association of Manufacturers (KAM). According to (KAM, 2019) there are 1,123 manufacturing firms registered in KAM directory 2019. To achieve optimum sample, this study followed the formula proposed by Saunder et al., (2016) since it is simple to use, scientific and can be used in cases of large populations. Thus, to calculate the sample size from 1,123 companies in Kenya, the study specified a $5 \%$ margin of error as shown in equation below:

$$
n=p \% * q \% *\left(\frac{z}{e \%}\right)^{2}
$$

Using the above formula, a study sample of 295 companies was derived.

The study used questionnaires with closed and open questions to collect data from 295 manufacturing businesses.

Both quantitative and qualitative techniques were adopted in the analysis of the collected data. The data was scrutinized and cleaned for any errors and coded in SPSS version 24. Using the coded data, the researcher generated tables, graphs and pie-charts which were used in presenting the results of the study. Qualitative data was checked through and compared based on the relevancy and presented in form of explanations. Regression analysis was carried out to test for the relationship between the independent variables and the dependent variable.

\section{Findings}

\section{Contractual Risk}

The study sought to assess the influence of contractual risk on the performance of manufacturing firms in Kenya. The findings are as shown in Table 1 . The findings compare with those by Huo et al., (2015) who established that through sharing ideas and decision making platforms, a company risks losing confidential information to competitors. The findings are also in concurrence with those by Mbachu, and Taylor (2014) who established that the contractual risk arising due to poor implementation of contracts by the contractors and disclosure of confidential information would affect the success and performance of organization by making them lose to the competitors. 
Table 1: Descriptive Results on Contractual Risk

Statements

MeanStd.

Dev.

Our company has had incidences of confidential information leak

3.251 .33

The service providers are clearly guided on the information that should not be2.90 1.58 shared before the contract is signed

Our company has policies against a contractor or any other individual breaching3.01 1.45 the confidential information

The parties found to breach any confidentiality are held individually responsible3.02 1.43

The company has previously suffered a low due to breach of confidentiality $\begin{array}{lll}2.96 & 1.55\end{array}$

Outsourcing has led to lack of Confidentiality on shared business strategy $\quad \begin{array}{lll}2.93 & 1.46\end{array}$

There are incidences where the lengthy hierarchy of decision-making have3.12 1.43

affected the process flow in the firm

There have been cases of quality of service inferior to expectations $\quad 3.001 .38$

There have been cases of poor relationship with the outsourced firms $\quad 3.611 .14$

There have been complains from the customers concerning outsourced firms 2.761 .34

There are a times when our company has failed to solve emergency problems3.24 1.08

in time

There are incidences where the contracted firm has failed to deliver the2.82 1.36 projected results

We have previously selected service providers inappropriately leading to poor2.91 1.41 results

Some of the outsourced firms have been inflexible leading to ineffectiveness $\begin{array}{lll}2.67 & 1.32\end{array}$

There have been some contractors who have recorded delay in contract2.71 1.38

implementation

There have been incidences of unclear dispute settlement procedures in our2.72 1.44

company

\section{Information Flow}

The study sought to assess the moderating effect of information flow on the relationship between contractual risk and performance of manufacturing firms in Kenya. The findings are as shown in Table 2. The findings compare with those by Yousefi, and Alibabaei (2015) who found out that through effective communication and information sharing, the operations flow more efficiently thus leading to better organizational performance.

Mukaddes et al (2010) argued that as a result of poor information flow between the outsourced firms and the outsourcing entities, it became difficult to coordinate activities effectively for mutual benefit. Liu et al (2015) also indicated that the information sharing within and out of the organization was essential in steering the effectiveness of operations thus enhancing customer satisfaction and continued performance. 
Table 2: Descriptive Results on Information Flow

Statements

MeanStd.

Dev.

Our company has not adopted the latest information technology to aid3.23 1.07 communication in and out of the company

The hierarchy of communication in our organization is only based on top-3.79 1.01 bottom approach

Giving feedback to the customers has not been effectively upheld in our2.56 1.32 company

The employees do not give and receive feedback to the management timely and2.58 1.33

efficiently

There are no effective approaches and strategies to ensure the internal2.11 1.56

information of the organization is not leaked

There are is unequal sharing of information among the employees in our3.36 1.34 organization

Staff members are held responsible in cases of leakage or misuse of internal3.45 1.32 organizational information

For any information shared the recipients are informed on the level of3.42 1.36 confidentiality on such information

There is no clarity in the information shared in our organization

3.541 .21

The management has not been committed towards ensuring consistency in3.34 1.33

information sharing in and out of the firm

The communication procedures in our company are not flexible

3.411 .41

There have been cases of inaccurate information being shared in our3.81 0.98 organization

\section{Performance of Manufacturing Firms}

The findings as shown in Figure 2 revealed that the performance trend of the manufacturing industry has been unstable with declines in revenues recorded the year 2016 and 2017 (from Kshs3,490 million to Kshs2,932 million) and from Kshs.4,085 million in the year 2019 to Kshs.2,716 million in the year 2020. The same trend was observed in the average profit margins where decline in the average profits was seen 2016 and 2017 and between 2019 and 2020. While this trend could be attributed to other aspects outside the logistics outsourcing risks, there could also be a high likelihood of lack of effective logistic processes to have affected the performance (Li-jun, 2012; Shanker, Sharma, \& Barve, 2021; Elock, Müller, \& Djuatio, 2019). 


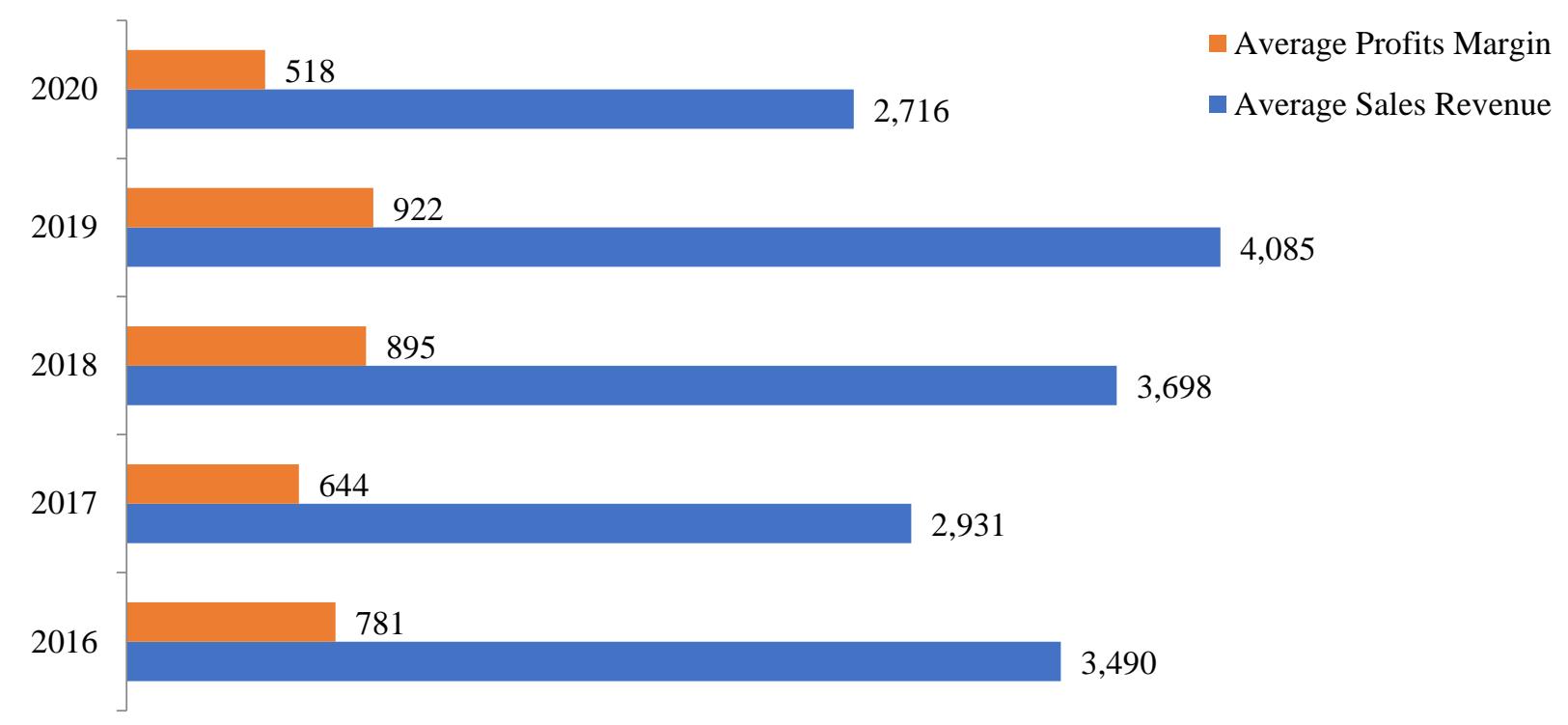

Figure 2: Performance of Manufacturing Firms

\section{Inferential Analysis Results}

\section{Correlation Analysis}

As the results on Table 3 revealed, contractual risk had a Pearson correlation coefficient of 0.720 with performance at a significance level of 0.000 , an indication that there is a strong and significant correlation between contractual risk and performance of manufacturing firms in Kenya.

Table 3: Correlation Results for Contractual Risk

\begin{tabular}{llll}
\hline & & $\begin{array}{l}\text { Performance } \\
\text { Manufacturing Firms }\end{array}$ & ofContractual Risk \\
\hline Performance & $\begin{array}{c}\text { Pearson } \\
\text { ofCorrelation } \\
\text { Manufacturing Firms }\end{array}$ & 1 & \\
& Sig. (2-tailed) & & \\
& $\mathrm{N}$ & 233 & 1 \\
& $\begin{array}{l}\text { Pearson } \\
\text { Contractual Risk }\end{array}$ & $.720^{* *}$ & \\
& Correlation & & 233 \\
& Sig. (2-tailed) & .000 & 233 \\
\hline
\end{tabular}

**. Correlation is significant at the 0.01 level (2-tailed).

\section{Regression Model}

$H_{A 1}$ : There is a positive significant influence of contractual risk on performance of manufacturing firms in Kenya

The regression model summary as shown in Table 4 revealed that the R-square $\left(R^{2}\right)$ was 0.518 . This is an indication that the $51.8 \%$ of the variation in performance of the manufacturing firms is as a results of the contractual risk. 
Table 4: Model Summary on Contractual Risk

\begin{tabular}{llllll}
\hline Model & $\mathrm{R}$ & $\mathrm{R}$ Square & Adjusted R Square & $\begin{array}{l}\text { Std. Error of the } \\
\text { Estimate }\end{array}$ & \\
\hline 1 & $.720^{\mathrm{a}}$ & .518 & .516 & .45647 & \\
\hline
\end{tabular}

a. Predictors: (Constant), Contractual Risk

The Analysis of Variance (ANOVA) results are as shown in Table 5. As the results reveal, the Fstatistic for the model was 248.625 at a significance level of $0.000<0.05$. This is an indication that the model is statistically significant to test the relationship between contractual risk and performance of manufacturing firms. It also implies that there is a likelihood of having a significant relationship between the two variables.

Table 5: ANOVA Results for Contractual Risk

\begin{tabular}{lllllll}
\hline Model & & Sum of Squares & Df & Mean Square & $\mathrm{F}$ & Sig. \\
\hline \multirow{2}{*}{1} & Regression & 51.804 & 1 & 51.804 & 248.625 & $.000^{\mathrm{b}}$ \\
& Residual & 48.132 & 231 & .208 & & \\
& Total & 99.936 & 232 & & & \\
\hline
\end{tabular}

a. Dependent Variable: Performance of Manufacturing Firms

b. Predictors: (Constant), Contractual Risk

The regression coefficients for the model are as shown in Table 6. As the results portray, the Beta coefficient for the model was 0.535 . This implies that a unit change in contractual risk would influence the performance of the manufacturing firms by $53.5 \%$. The P-value for the model is $0.000<0.05$. This implies that the relationship between contractual risk and performance of manufacturing firms is statistically significant. Therefore, the alternative hypothesis that there is a positive significant influence of contractual risk on performance of manufacturing firms in Kenya is accepted.

Table 6: Regression Coefficients for Contractual Risk

\begin{tabular}{lllllll}
\hline Model & \multicolumn{3}{l}{ Unstandardized Coefficients } & $\begin{array}{l}\text { Standardized } \\
\text { Coefficients } \\
\text { Beta }\end{array}$ & T & Sig. \\
& B & Std. Error & Beta & \\
\hline 1 & (Constant) & 1.356 & .103 & & 13.169 & .000 \\
& Contractual Risk & .535 & .034 & .720 & 15.768 & .000 \\
\hline
\end{tabular}

a. Dependent Variable: Performance of Manufacturing Firms

\section{$H_{A 2}$ : There is a positive significant moderating effect of information flow on influence of} Contractual risk and performance of manufacturing firms in Kenya

The study set to test the hypothesis that information flow has a significant moderating effect on the relationship between contractual risk and performance of manufacturing firms in Kenya. The regression coefficients for the moderated model are as shown in Table 7. As the results portray, the interaction effect between contractual risk and information flow had a Beta coefficient of 0.043 at a significant level of $0.007<0.05$ an indication that there is a significant moderating effect of information flow on the relationship between contractual risk and performance of the manufacturing firms. 
Table 7: Regression Coefficients for the Overall Moderated Model

\begin{tabular}{llllll}
\hline Model & \multicolumn{2}{l}{ Unstandardized } & \multicolumn{2}{l}{$\begin{array}{l}\text { Standardized T } \\
\text { Coefficients }\end{array}$} & Sig. \\
& $\mathrm{B}$ & Std. Error & $\begin{array}{l}\text { Coefficients } \\
\text { Beta }\end{array}$ & \\
\hline (Constant) & 1.553 & .093 & & 16.678 & .000 \\
Contractual & .043 & .016 & .250 & 2.730 & .007 \\
Risk*Information Flow & & & & & \\
\hline
\end{tabular}

a. Dependent Variable: Performance of Manufacturing Firm

\section{Conclusion and Recommendations}

The results of the study revealed that incidences of information leakages, lack of clear guidance of the service providers in regard to confidential information as well as unavailability of clear and well formulated policies on how to guide confidential information were some of the risk that the companies encountered.

The study concluded that contractual risk was one of the logistics outsourcing risks that significantly influenced the performance of the manufacturing firms in Kenya. The breaches of confidentiality such as leakage of internal information to the competitors as well as failure of the outsourced suppliers to retain confidentiality of the shared information were among the contractual risk affecting the performance of the manufacturing companies. It was concluded that the business continuity risk through establishment of continued collaboration between the suppliers and the manufacturing companies as well as failures to perform as expected were key contractual risk whose impact could be detrimental to the manufacturing firms.

The management of the manufacturing firms through the supply chain and logistics departments should embrace key strategies of managing contractual risk as a way of enhancing the continued performance of the manufacturing firms. There are incidences of the contractor breaching confidentiality as well as the exposure of confidential information being exposed to the competitors. Such situations could have dire consequences on the organization, hence the need for the organization to uphold effective control measures for the contractors to adhere to the confidential policies. The business continuity with the suppliers as well as contract failures should be monitored to ensure such risks are managed on time, for enhanced performance.

\section{References}

Bordens, K. S., \& Abbott, B. B. (2014). Research design and methods: A process approach (9thEd.) San Francisco: McGraw Hill

Elock, S. C., Müller, J., \& Djuatio, E. (2019). Logistic outsourcing risks management and performance under the mediation of customer service in agribusiness. In Supply Chain Forum: An International Journal (Vol. 20, No. 4, pp. 280-298). Taylor \& Francis.

Gitahi, S. M., \& Tumuti, J. (2019). Management of contracting risks on performance of construction projects in Kilifi County, Kenya. International Academic Journal of Information Sciences and Project Management, 3(3), 105-130.

Hsiao, H. (2010). A classification of logistic outsourcing levels and their impact on service performance: Evidence from the food processing industry, Int. J. Prod. Econ., vol. 124, no. 1 , pp. $75-86$ 
Huo, B., Ye, Y., \& Zhao, X. (2015). "The impacts of trust and contracts on opportunism in the 3PL industry: The moderating role of demand uncertainty", International Journal of Production Economics, Vol. 170, pp. 160-170.

Li-jun, Z. (2012). Research on analysis and control of enterprise logistics outsourcing risks. Energy Procedia, 17, 1268-1273.

Liu, C., Huo, B., Liu, S., \& Zhao, X. (2015). Effect of information sharing and process coordination on logistics outsourcing. Industrial Management \& Data Systems, Vol. 115 No. 1, pp. 41-63.

Luo, W. (2008). The theories and cases of the third party logistics. 1st ed. Shanghai: Shanghai Science institute Press.

Mbachu, J., \& Taylor, S. (2014). Contractual risks in the New Zealand construction industry: Analysis and mitigation measures. International Journal of Construction Supply Chain, 4(2), 22-33.

Mokrini, A., Dafaoui, E., Berrado, A., El Mhamedi, A. (2016). An approach to risk Assessment for Outsourcing Logistics: Case of Pharmaceutical Industry. IFAC-Papers OnLine 49, 1239-1244.

Mukaddes, M. A. M., Choudhury, R. A., \& Javed, K. (2010). "Developing an information model for supply chain information flow and its management," International Journal of Innovation, Management and Technology, pp. 226-23.

Saunders M., Lewis P., \& Thornhill A., (2016). Research Methods for business students. Pearson Education Limited.

Sauvage, T., \& Haouari, M. (2011). Risk management: A new way to improve logistics outsourcing, In Supply Chain Innovation for Competing in Highly Dynamic Markets: Challenges and Solutions, IGI Global, pp. 315-331.

Shanker, S., Sharma, H., \& Barve, A. (2021). Assessment of risks associated with third-party logistics in restaurant supply chain. Benchmarking: An International Journal, https://doi.org/10.1108/BIJ-06-2020-0343

Waters, D. (2011). Supply Chain Risk Management: Vulnerability and Resilience in Logistics. Kogan Page Publishers,

Yousefi, N., \& Alibabaei, A., (2015). Information flow in the pharmaceutical supply chain. Iran. J.Pharm. Res. IJPR 14, 1299-303.

Zailani, S., Mohd, R. S., Khairul, R., \& Mohammad, I. (2017). Influential factors and performance of logistics outsourcing practices: an evidence of Malaysian companies. Review of Managerial Science

Zhu, W., Ng, S. C. H., Wang, Z., \& Zhao, X. (2017). The role of outsourcing management process in improving the effectiveness of logistics outsourcing. International Journal of Production Economics, 188, 29-40. 